\title{
Yrkesfaglig praksis i bachelorutdanningen for yrkesfaglærere: En kartlegging av studentenes erfaringer
}

\author{
(Vocational practice in bachelor education for vocational teachers: \\ A survey of the students' experiences)
}

\author{
Klara Rokkones, Berit Stjern, Åse Strand, \\ Britt Karin Utvær
}

Norges teknisk-naturvitenskapelige universitet, Norge

(klara.rokkones@ntnu.no)

\begin{abstract}
This study examines experiences of vocational teacher students in practice at work places. The aim is to develop and ensure that the practice is in accordance with the purpose of the Vocational Teacher Education programme in terms of relevance, coherence and supervision. The analysis is based on open and closed responses to an annual student survey during a period of ten years. The study shows that vocational practice at work is of great importance for learning about different professions and work functions in the students' study programme. Vocational practice at work is found to be helpful in the process of making teaching more practical, linking theory and practice together in a better manner, guiding students in their choice of career and network building. The study also demonstrates that there is a stronger link between students' satisfaction with vocational practice, relevance and guidance in their third year of study, than was the case in their first year. There appears to be a development from the first to third year of study where students go from experiencing the study more fragmented, to viewing the whole of the study and its purpose more clearly. Experience of relevance, along with good supervision, largely explains how satisfied the students are with the vocational practice.
\end{abstract}

Keywords: vocational teacher education, vocational practice, relevance, supervision, curriculum 


\section{Innledning}

Artikkelen tar utgangspunkt i yrkesfaglig praksis som er en sentral del av den treårige bachelorutdanningen for yrkesfaglærere i Norge. Formålet med yrkesfaglig praksis er at studentene skal bli kjent med flest mulig av yrkene som inngår i utdanningsprogrammet samt få mulighet til faglig fordypning innenfor eget fagbrevområde (Kunnskapsdepartementet, 2013a).

Etter innføringen av Kunnskapsløftet i 2006 ble antall yrkesfaglig utdanningsprogram betraktelig redusert. Det medfører at lærere som underviser på videregående trinn 1 (Vg1) har behov for bred kompetanse for å favne bredden i fagog yrkeskompetanser innenfor eget utdanningsprogram. Forskning viser at det er utfordrende for yrkesfaglærere å undervise på de brede Vg1-programmene og lede opplæringen mot andre yrker enn sitt eget (Spetalen, 2014).

Samtidig kvalifiserer utdanningen til undervisning på videregående trinn 2 og 3 (Vg2 og Vg3) innenfor eget fagbrevområde. Forskningen peker på at lærernes behov for oppdatert kunnskap og relevant praksis fra yrkeslivet kan oppnås gjennom et tett samarbeid med arbeidslivet, hospiteringsordninger og nettverksbygging (Andersson \& Köpsén, 2018; Fejes \& Köpsén, 2014; Hansen, Hoel \& Haaland, 2015; Hiim, 2015).

Etter mange år med treårig yrkesfaglærerutdanning er det lite dokumentasjon på hvilken betydning yrkesfaglig praksis har for studentenes læring og profesjonsutvikling. En nasjonal evaluering av yrkesfaglærerutdanningen viser tydelig at yrkesfaglærerutdannerne ser på yrkesfaglig praksis som svært viktig, mens studentenes perspektiv er lite utforsket (Brandt \& Hatlevik, 2003). En ny studie med fokus på yrkesfaglærernes kompetanse viser at lærere etterspør særlig kompetanseutvikling knyttet til endringer i arbeidslivet og behovet for faglig oppdatering knyttet til de yrkene elevene skal ut i (Aspøy, Skinnarland \& Tønder, 2017). Arbeidslivets ansvar for kvalifisering av profesjonsutøvere er ofte i mindre grad blitt tematisert når kompetansen til profesjonsutøvere diskuteres (Smeby \& Mausethagen, 2017) på tross av formaliserte avtaler. Det er derfor et stort behov for mer kunnskap om hvilken betydning yrkesfaglig praksis har for profesjonskvalifiseringen til yrkesfaglæreren.

Hensikten med denne studien er derfor å kartlegge studentenes erfaringer med yrkesfaglig praksis for å videreutvikle denne delen av studiet slik at den er i samsvar med studiets formål. Tidligere forskning viser at læring gjennom praksis i bedrift er sentralt i utvikling av yrkesfaglig kompetanse generelt og oppleves som en god læringsform for mange yrkesutøvere (Fejes \& Köpsén, 2014; Hilsen, Nyen \& Tønder, 2012). Forskning på lærere som hospiterer i fag de ikke kjenner så godt fra før, viser at hospitering kan gi et innblikk i helheten i yrket, ikke bare i de faglige kravene, men også hvordan det er å stå i yrket (Hilsen m.fl., 2012). Hospitering er et prioritert satsningsområde i Yrkesfaglærerløftet, en nasjonal strategi for å styrke kompetansen til yrkesfaglærere (Kunnskapsdepartementet, 
2015). Dette har overføringsverdi til yrkesfaglig praksis for yrkesfaglærerstudenter hvor formålet er fordypning i eget fagbrevområde og kjennskap til mangfoldet av yrkene innenfor eget utdanningsprogram. Fremtidens yrkesfaglærere skal utdanne fremtidens fagarbeidere. I et arbeidsliv i rask utvikling kreves det lærere som er vant til omstilling, som engasjert følger utviklingen i sitt eget fag og som gir opplæring i samsvar med behovene $i$ arbeidslivet (Kunnskapsdepartementet, 2015).

Studentene utdannes til å ha bred innsikt i den norske fag- og yrkesopplæringen som hovedsakelig er organisert i en $2+2$ modell, to år i skole ${ }^{1}$ og to års læretid i bedrift ${ }^{2}$. Læreplanen for opplæringen i skole (Vg1+Vg2) består av allmenne fag, yrkesfag og praksis i skole på f.eks. verksted og kjøkken, eller andre praksisarenaer som er relevante for utdanningsprogrammet. I tillegg har elevene praksis ute i bedrifter/virksomheter, Yrkesfaglig fordypning. Læretiden i bedrift (Vg3) er hovedsakelig praktisk arbeid.

Læreplanen er delt mellom teoretiske og praktiske fag som utfordrer fag- og yrkesopplæringens mål om relevans, helhet og sammenheng i opplæringen (Heggen, Smeby \& Vågan, 2015; Nyen \& Tønder, 2012). Opplevelsen av mangel på relevans opp mot elevenes fremtidige yrkesønsker er en kritikk som hyppig rettes mot opplæringen i skole (Hansen \& Haaland, 2015; Hiim, 2013, 2015). I tillegg erfarer elever at det ofte er mangel på helhet og sammenheng mellom de ulike læringsarenaene som klasserom, verkstedpraksis i skolen og praksis ute i bedrift/virksomhet. Frafallet i fag- og yrkesopplæringen i Norge har lenge vært en utfordring. Forskning peker på at dette kan være relatert til nettopp mangel på relevans og yrkesidentifisering (Hiim, 2015; Utvær \& Haugan, 2016).

Forskrift om rammeplan for yrkesfaglærerutdanning for trinn 8-13 (Kunnskapsdepartementet, 2013b) understreker at praksis skal være relevant. Yrkesfaglig praksis gir studentene anledning til å oppdatere seg faglig gjennom deltagelse og observasjon. Videre presiserer den at den yrkesfaglige praksisen skal være veiledet i den konteksten faget utøves. I tillegg sier forskriften at yrkesfaglig praksis skal inngå som en integrert del av yrkespedagogisk praksis, profesjonsfaget og yrkesfaget. Til sammen utgjør dette de faglige komponentene i utdanningen (Figur 1). Utdanningen skal organiseres på en måte som sikrer progresjon og sammenheng mellom komponentene. 


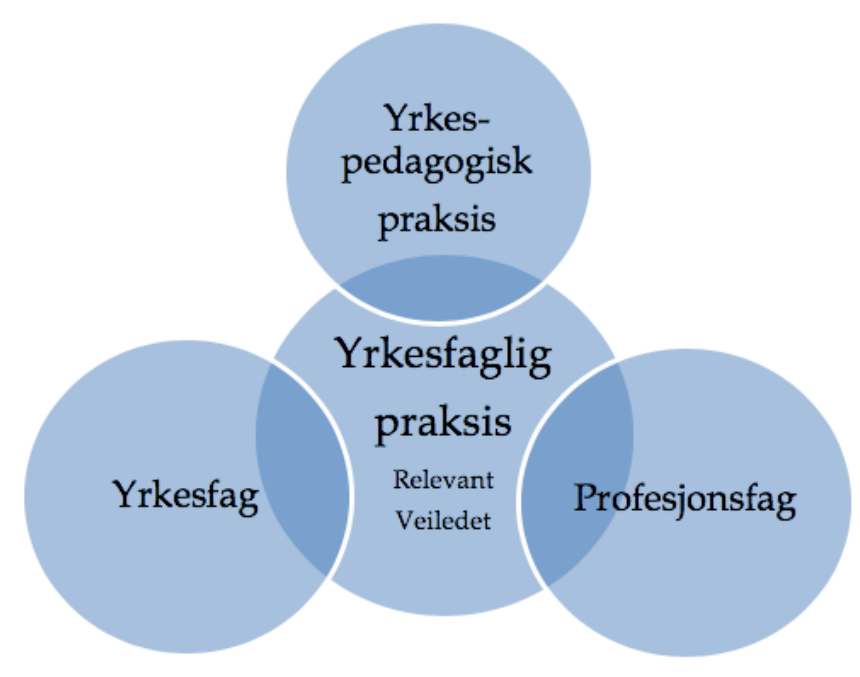

Figur 1. Norsk yrkesfaglærerutdannings faglige komponenter.

Med bakgrunn i forskriften (Kunnskapsdepartementet, 2013b) som utgjør studiets formelle læreplan vil artikkelen fokusere på tre sentrale områder - studentenes erfaringer med relevans, sammenheng og veiledning i yrkesfaglig praksis. Studien dreier seg om hvorvidt studentene opplever at deres bredde- og dybdekompetanse oppnådd gjennom yrkesfaglig praksis er relevant for deres fremtidige profesjonsutøvelse. Studien ser videre på om studentene opplever sammenheng mellom studiets fire komponenter og betydningen av veiledning i yrkesfaglig praksis. Vi ser også på hvordan studentenes erfaringer endrer seg gjennom studiet. Følgende problemstilling belyses: Hvordan kan vi forstå studentenes opplevde relevans, sammenheng og veiledning i yrkesfaglig praksis, og hvordan endres disse gjennom utdanningsløpet?

Videre i artikkelen presenteres den treårige yrkesfaglærerutdanningen og vår teoretiske tilnærming.

\section{Treårig yrkesfaglærerutdanning}

I forskrift om rammeplan for yrkesfaglærerutdanning (Kunnskapsdepartementet, 2013b) står det at studentene skal ha 60 studiepoeng $i$ henholdsvis yrkesfaglig bredde, yrkesfaglig dybde og profesjonsfag. Videre sier forskriften at det skal være 60 dager veiledet yrkesfaglig praksis knyttet til arbeidslivet og 70 dager veiledet yrkespedagogisk praksis knyttet til skole. Dagene fordeles likt mellom de tre studieårene unntatt 2. studieår hvor yrkespedagogisk praksis utgjør 30 dager. Veiledningsressursene omfatter 60 timer fra instruktør/faglig leder i bedrift/virksomhet og 112 timer fra pedagogisk personale ved praksisskolen (Kunnskapsdepartementet, 2013a). 
Treårig yrkesfaglærerutdanning ved Norges teknisk-naturvitenskapelige universitet (NTNU) ble etablert i 2007 og er et samlingsbasert studium. Yrkesfaglig praksis ved NTNU kan organiseres i perioder på 2 eller 4 uker, unntaksvis i enkeltuker i yrker der praksis hovedsakelig består av observasjon. Studentene har selv ansvar for å skaffe seg praksisplasser, både i skole og bedrift. Yrkesfaglærerutdanningen kvalifiserer studenter for å undervise på brede Vg1 som leder mot flere yrker (komponenten yrkesfaglig bredde) og på Vg2 innenfor studentens eget fagbrevområde (komponenten yrkesfaglig dybde). I første og andre studieår har studenter ved NTNU primært yrkesfaglig praksis i andre yrker enn eget fagbrevområde mens tredje studieår er oftere knyttet til fordypning innenfor eget yrke. I tillegg til å undervise i videregående skole blir studentene kvalifisert for å jobbe på ungdomstrinnet $\mathrm{i}$ fag som er knyttet opp til deres eget fagbrevsområde, for eksempel mat- og helse, utdanningsvalg, arbeidslivsfag og adekvate valgfag. Emnebeskrivelser for praksis (NTNU, 2017) fremhever betydningen av praksiserfaringer i utviklingen av både yrkesfaglig og profesjonsfaglig kompetanse. Det er essensielt at studenten får innsikt i det daglige arbeidet og yrkesprosesser på arbeidsplassen.

\section{Teoretisk forankring}

Studentenes læring, læringsprosesser og læringsutbytte er sentrale begrep i all utdanning. I dette kapittelet presenteres vår læreplanforståelse og ulike læreplannivåer. Deretter beskrives ulike teoretiske perspektiver på hva som fremmer læring gjennom praksis i yrkesfaglærerutdanningen.

\section{Goodlads læreplannivåer}

Læreplaner kan betraktes fra ulike synsvinkler. John Goodlad (1979) har skissert fem læreplannivåer som et begrepssystem for læreplanforståelse. Goodlad ser på de ulike nivåene som et redskap for å undersøke læreplanpraksis som en del av pedagogisk praksis. I denne studien benyttes Goodlads fem læreplannivåer for å synliggjøre nivåene i læreplanen for treårig yrkesfaglærerutdanning. Hensikten er å øke forståelsen for forholdet mellom ideene bak læreplanen, den formelle læreplanen, hvordan yrkesfaglærerutdannere forstår og iverksetter den og til sist hvilke erfaringer studentene gjør seg. Ideenes læreplan eller den ideologiske læreplan er det første nivået. Dette nivået viser til ideer som blir fremmet i debatt om skole, utdanning og faglig undervisning. Ideene har bakgrunn i filosofiske ideer eller de kan fremmes ut fra forhold som angår næringsliv eller arbeidsmarkedet (Engelsen, 2012). Mangel på yrkesfaglærere og fremtidens behov for yrkesfaglærere er to forhold som gjerne blir lagt til grunn for utviklingen av mer formelle læreplaner. Det er også en idé at andelen lærere med fag- og yrkeskompetanse bør økes i grunnopplæringen slik at elevene får flere faglige forbilder (Høst, 2010; Skålholt, Høst, Nyen \& Tønder, 2013). Den formelle læreplanen er det neste nivået. 
Her er ideene formalisert i læreplandokumenter som utgjør en ramme for skolen og lærerens virksomhet (Engelsen, 2012). Forskrift om rammeplan for yrkesfaglærerutdanning for trinn 8-13 (Kunnskapsdepartementet, 2013b) er en slik formell læreplan. Det samme gjelder studieplaner som utdanningsinstitusjonene utarbeider. I denne studien vises det til forskriften og den lokale studieplanen inkludert emnebeskrivelsene. Det tredje nivået er den oppfattede læreplanen. Kompetansemål, råd og retningslinjer i den formelle læreplanen tolkes av yrkesfaglærerutdannere, og det er denne tolkningen som blir utgangspunktet for planlegging, tilrettelegging, tenkt gjennomføring og vurdering av opplæringen (Engelsen, 2012). Dette tredje nivået har størst innflytelse på organisering og realisering av læreplanen. Den operasjonaliserte læreplanen er det fjerde nivået, og nivået beskriver undervisningen slik den faktisk blir gjennomført innenfor læreplanens rammer (Engelsen, 2012). Det vil si den oppfattede læreplanen omsatt i praksis. Det femte og siste nivået er den erfarte læreplanen. Dette vil omfatte studenters erfaringer med og opplevelser av undervisning og opplæring. Den erfarte læreplanen kan variere ut fra hver enkelt students erfaringer og individuelle forutsetninger (Engelsen, 2012). Denne studiens formål er å kartlegge studentenes erfaringer med relevans, sammenheng og veiledning i yrkesfaglig praksis og hvordan disse erfaringene endres i løpet av utdanningsløpet.

\section{Læring gjennom yrkesfaglig praksis}

Interessen for læring på arbeidsplassen er stor. En del av bakgrunnen for dette ligger i de generelle problemene for læring i de institusjonaliserte utdanningene (Illeris, 2012). Det tar for lang tid for institusjonene, som videregående skole og universitet, å justere seg og følge opp de raske endringene som skjer i et moderne samfunn. En av begrunnelsene for at studenter på yrkesfaglærerutdanningen skal ha yrkesfaglig praksis, er at de skal bli mest mulig oppdatert på det nyeste innenfor sitt programområde. Dette kan ikke lærerutdanningen alene klare å følge opp, her må et viktig samarbeid med bedrifter og virksomheter finne sted.

Studentenes yrkesfaglige praksis innebærer at de skal lære gjennom utøvelse av praktiske arbeidsoppgaver. Arbeidsoppgavene er knyttet til ulike fagbrev og yrkeskompetanser innenfor eget utdanningsprogram. Lave og Wenger (2003, 2004) beskriver dette som situert læring. De sier at læring må sees i sammenheng med konteksten den blir anvendt i. Lave og Wenger ga små læringsfellesskap som ble lokalisert i det daglige arbeidet, benevnelsen Communities of Practice. På norsk har begrepet fått benevnelsen praksisfellesskap som beskriver uformelle, lærende samarbeidsgrupper som grunnlag for kompetanseutvikling. Ofte vil det være slike fellesskap studentene får erfaring med i sin yrkesfaglige praksis. Fellesskapene er ikke nødvendigvis tids- eller stedsavhengige. De er heller ikke avhengige av definerte strukturer eller styring. Læringen er ikke formell som i en utdanningsinstitusjon, men skjer som følge av delt sosial praksis, gjennom relasjoner og samhandling i fellesskapet (Lave \& Wenger, 2003, 2004). 
Schön $(1982,1987)$ legger også vekt på læring i praksisfellesskap og understreker at det som kjennetegner profesjonell kompetanse, er evnen til refleksjon i handling. I yrkeslivet møter studentene situasjoner som er unike i den forstand at de må forståes i den kontekst de er en del av. Studentenes mulighet til refleksjon blir dermed sentral for læringsutbyttet, noe som understøttes av flere studier innenfor høyere utdanning (Ramlo, 2016; Rautkorpi \& Hero, 2017). Hiim og Hippe (2001) understreker viktigheten av å se praksis i sammenheng med teori. Det innebærer at yrkesfaglærerutdannere må legge til rette for arbeidsoppgaver, arbeidskrav og tid til refleksjon slik at studentene opplever mening og ser sammenhenger mellom det de lærer i praksis og på campus.

McNiff (2013) bruker begrepet skjult ("tacit") kunnskap, hun sier at denne type kunnskap læres best i praksis. I denne studien tolkes begrepet skjult kunnskap dithen at det går på praktisk utøvelse av yrker (teknikker, håndlag, fingerspissfølelse) som det er ønskelig at studentene får mulighet til å utøve i yrkesfaglig praksis. Nyutdannede lærere blir i litteraturen ofte omtalt som noviser som gjennom profesjonell praksis kan utvikle seg til eksperter (Dreyfus \& Dreyfus, 1986). Ekspertiselitteraturen viser at skolebasert kunnskap er utilstrekkelig, men det er også praksis (Smeby \& Mausethagen, 2017). Profesjonskvalifisering forutsetter trening i praksis kombinert med veiledning og tid til refleksjon.

\section{Profesjonsrelevant yrkesfaglig praksis}

Hiim og Hippe (2001) beskriver at det innenfor forskningsbasert kunnskap om yrkes- og profesjonsutdanninger savnes profesjonsrelevans for den praktiske yrkesutøvelsen. Problemene de peker på innebærer at studentene ofte oppfatter teoriundervisning som lite meningsfylt og nyttig, mens praksisundervisningen i skole og bedrift lever sitt eget liv løsrevet fra teorien. I Rammeplan for yrkesfaglærerutdanning (Kunnskapsdepartementet, 2006) beskrives praksisopplæring i en særstilling med tanke på at studentene oppnår relevant og tilstrekkelig kompetanse. Relevans og læring i yrkesfaglig praksis betinger sammenheng i yrkesinnhold og utdanningsinnhold (Hiim, 2013, 2015); dette gjelder så vel elever som yrkesfaglærerstudenter. Lærerstudentene må erfare sammenhengen mellom det de lærer som studenter og hva de må kunne som ferdigutdannede yrkesfaglærere. De må kunne veilede elever i deres yrkesvalg, de må kunne samarbeide med opplæringsbedrifter, ha inngående kunnskap om ulike yrker, kunne yrkesdifferensiere og legge til rette for en tilpasset opplæring for alle elever. Annen forskning bekrefter disse kvalitetskriteriene for å kunne legge til rette for en relevant fag- og yrkesopplæring (Hansen, Hoel, \& Haaland, 2015).

\section{Sammenhenger mellom yrkesfaglig praksis og studiets øvrige komponenter}

Forskrift om rammeplan for yrkesfaglærerutdanning for trinn 8-13 (Kunnskapsdepartementet, 2013b) sier at utdanningen skal være av høy faglig kvalitet med helhet og sammenheng mellom profesjonsfag, yrkesfag og praksis. Det finnes 
ulike perspektiver på sammenheng (koherens) i lærerutdanningene. Ett av dem fokuserer spesielt på lærings- og mestringsperspektivet. I et slik perspektiv fremstår koherens som studentenes muligheter til å håndtere spenninger og skape opplevelse av sammenhenger i utdanningen. Koherens forstås som meningsdanning, og som noe en søker etter, der ulike emner og erfaringer ses opp mot og forstås i lys av hverandre (Hatlevik \& Havnes, 2017).

Det er en utfordring i profesjonsutdanningene at kunnskapselementer fra ulike fagfelt ikke henger godt nok sammen og at det er en svak kobling mellom læring på ulike læringsarenaer (Hatlevik \& Havnes, 2017). Når studentene deltar og opplever helhet, sammenheng og relevans, fører dette til bedre læringsutbytte (Aamodt, Prøitz, Hovedhaugen \& Stensaker, 2007). Jo sterkere sammenhengen er mellom de ulike komponentene i studiet, jo bedre er studiekvaliteten (Hammerness, 2013). Forskning viser at det å legge til rette for helhetlig læring er krevende (Brandt \& Hatlevik, 2003) og at helhetlig læring og det å se sammenhenger krever tid til refleksjon (Hiim, 2007).

\section{Veiledning i praksis}

Tveiten (2013) beskriver veiledning som en formell, rasjonell og pedagogisk istandsettingsprosess som har til hensikt at å styrke mestringskompetanse gjennom dialog basert på kunnskap og humanistiske verdier. I yrkesfaglig praksis vil studentene ofte møte mesterlæretradisjonen som baseres på at lærlingen lærer ved å se på hva mesteren gjør. Tveiten (2013) påpeker videre at mesterens kompetanse i yrkesfagene er relatert til yrkesfunksjoner eller håndverk, ikke primært $\mathrm{i}$ å veilede noen. Mesteren besitter verdifull, taus kunnskap som kun kan formidles gjennom å utføre en spesifikk arbeidsoperasjon, noe som medfører at mesterlæretradisjonens kunnskapsformidling er vesentlig. Denne type veiledning har større fokus på mesteren sammenlignet med opplæringssituasjoner der det legges til rette for at lærlingen skal være aktiv mens veilederen ser på. Veiledning innebærer langt mer enn bare formidling av kunnskap. Læring skjer hos den enkelte gjennom aktive prosesser (Benner, 1983; Schön, 1982, 1987), og det er derfor viktig at studentene får prøve ut autentiske arbeidsoppgaver under veiledning.

\section{Metode}

\section{Datainnsamling og utvalg}

Datamaterialet i studien er samlet inn gjennom årlige studentundersøkelser ved NTNUs treårige yrkesfaglærerutdanning i perioden 2008-2017. Studentene er erfarne fagarbeidere med fagbrev/yrkeskompetanse innenfor de fem studieretningene helse- og oppvekstfag, elektrofag, bygg- og anleggsteknikk, teknikk og industriell produksjon og restaurant- og matfag. NTNU viser i sine årsrapporter at aldersspredningen er fra 24 til 58 år med en gjennomsnittsalder på cirka 38 år 
(se for eksempel NTNU, 2014). Datainnsamlingen er gjennomført som en elektronisk survey og omfatter totalt 597 svar gitt fra første, andre og/eller tredje studieår. Svarprosenten for de tre årskullene ligger mellom 60 og 65 prosent. Omtrent halvparten av de som har svart er fra helse- og oppvekstfag, 27 prosent fra de teknologiske fagene og 23 prosent fra restaurant- og matfag.

\section{Spørreundersøkelsene}

Antallet spørsmål har vært justert noe fra år til år. Spørsmålene om relevans og veiledning, som er inkludert i denne studien har ikke vært endret i perioden 2008-2017. Disse spørsmålene er stilt på en seks punkts skala som strekker seg fra 1 "helt uenig" til 6 "helt enig". Ett eksempel på spørsmål om opplevd relevans i praksis er som følger: "Yrkesfaglig praksis har vært relevant med tanke på å få relevant kompetanse og erfaring" mens ett eksempel på spørsmålene om relevans i undervisningen på campus lyder slik: "Undervisningen i yrkesfaglig bredde og yrkesfaglig dybde er relevant med tanke på formålet med yrkesfaglærerutdanningen". Spørsmål knyttet til veiledning i praksis er formulert slik: "Jeg er fornøyd med veiledningen knyttet til yrkespraksisen min". I tillegg ble det knyttet åpne spørsmål til de lukkede hvor studentene blir bedt om å komme med kommentarer til studiets faglige komponenter, eksempelvis yrkesfaglig praksis. Det er ikke spurt direkte om hvordan studentene opplever helhet og sammenheng i studiet. Dette undersøkes gjennom korrelasjons- og regresjonsanalyser av de ulike spørsmålene samt svarene på de åpne spørsmålene. I analysen benyttes både kvalitativ og kvantitativ tilnærming. De åpne spørsmålene er kodet og kategorisert i meningsbærende enheter (Kvale, Brinkmann, Anderssen \& Rygge, 2015; Postholm \& Jacobsen, 2014). Kategoriene relevans, sammenheng mellom studiets faglige komponenter og veiledning ble utviklet med utgangspunkt i forskrift om rammeplan for yrkesfaglærerutdanning (Kunnskapsdepartementet, 2013b). De lukkede spørsmålene i spørreundersøkelsene er analysert i SPSS (versjon 21). Først presenteres funn fra de åpne spørsmålene, deretter de lukkede.

Forfatterne er alle involvert i undervisning i studiet og i forberedelsene til yrkesfaglig praksis. ̊̊ forske på egen praksis har sine metodiske utfordringer som vi har prøvd å være bevisst. Våre erfaringer i møte med studentene er trukket inn i diskusjonen for å nyansere og utdype funnene, men det forsøkes å ha et tydelig skille mellom hva som er studentenes erfaringer og våre erfaringer som yrkesfaglærerutdannere.

\section{Funn åpne spørsmål}

\section{Relevans}

Studentene i alle tre studieår sier at den yrkesfaglige praksisen har stor betydningen for å lære om forskjellige yrker innenfor eget utdanningsprogram og at den har stor betydning for å lære om yrkenes egenart og arbeidsoperasjoner som 
de kan bruke i egen undervisning, både på Vg1 og Vg2. Undervisningen oppleves dermed å bli praksisnær, og de uttaler at det er lettere å legge opp undervisning i etterkant når man har praksiserfaring. Flere peker likevel på at 20 dager i samme bedrift er for lang tid, særlig hvis mye av tiden brukes til observasjon. De ville heller hatt mulighet til kortere praksisperioder, men innenfor flere yrker. En til to uker på hver plass er passe. Noen studenter føler at de er gratis medarbeidere for bedriften, noe som oppleves som demotiverende. Spesielt studenter med lang yrkeserfaring eller flere fagbrev/erfaring innenfor sitt utdanningsprogram ser yrkesfaglig praksis som mindre relevant. Disse studentene fremhever særlig at denne praksisen er sløsing av tid og foreslår en kartlegging av individuelle behov. Andre studenter etterspør en bedre organisering og tydeligere beskrivelse av hva de skal gjøre i yrkesfaglig praksis.

Andreårsstudenter påpeker i større grad at de er mettet etter åtte uker med yrkesfaglig praksis og lite motivert for mer selv om de omtaler den som lærerik. Enkelte sier at de er mindre motivert for yrkesfaglig praksis enn yrkespedagogisk praksis, og ønsker totalt sett mindre yrkesfaglig praksis i studiet.

I tredje studieår sier flere studenter at yrkesfaglig praksis får stor betydning sett i ettertid, og uttrykker at den er helt nødvendig for å få innsikt og innblikk i yrkene. Mange peker på at de har fått prøvd ut yrker de kunne lite om på forhånd. Samtidig sier studentene at det har vært strevsomt, men verdt hver time. Flere påpeker at praksisen gir muligheter til å oppdatere og fordype seg i eget fagbrevområde. Den yrkesfaglige praksisen er i følge noen tredjeårsstudenter like viktig som yrkespedagogisk praksis og kan ikke erstattes på noen som helst måte. De ser også nytteverdi av yrkesfaglig praksis for fremtidig jobb, enkelte nevner i denne sammenheng praksis på opplæringskontor og muligheten for å arbeide som veileder i bedrift.

Sammenhenger mellom studiets faglige komponenter

Studenter fra første studieår sier at yrkesfaglig praksis skaper større forståelse for emnene i studiet og at yrkesfaglig praksis knytter teori og praksis bedre sammen. Samtidig sier studentene at de opplever det lettere å legge opp undervisning i yrkespedagogisk praksis når man har praksiserfaringer. Kjennskap til arbeidsfunksjoner og -oppgaver er svært nyttig med tanke på kunnskapsoverføring til egne elever. Større innsikt i dette oppleves å være til god hjelp i undervisningen og veiledning i faget Yrkesfaglig fordypning, spesielt på Vg1, hvor elevene har behov for hjelp knyttet til yrkesvalg. I andre og tredje studieår konkretiser og understreker studentene i større grad betydningen av kunnskap og erfaringer fra yrkesfaglig praksis. Flere av studentene svarer at de opplever at studiet er bra og har gitt dem et mer helhetlig bilde på undervisning og bruk av undervisningsmetoder. De påpeker videre at yrkesfaglig praksis er viktig for å knytte kontakter og bygge nettverk. 


\section{Veiledning}

Flere studenter fra alle tre studieår svarer at de fikk god veiledning av flinke veiledere og hadde en god praksisopplevelse. Dette uttrykkes ofte i samme setning. Andre studenter svarer at de fikk lite oppfølging og få tilbakemeldinger; de opplevde at veilederne var lite tilgjengelige, uforberedte, tafatte eller hadde dårlig kompetanse.

I tredje studieår påpeker noen studenter at utbyttet av yrkesfaglig praksis er veldig avhengig av veilederne. Andre sier at yrkesfaglig praksis er lærerik selv om ikke veiledningen alltid var like god. Et par studenter sier at praksisperiodene i stor grad er hva man selv gjør dem til; med økt bevissthet på hva som er formålet med praksisen kan man sørge for å velge steder og veiledere som har nødvendig kompetanse og engasjement for å få en god praksisopplevelse. En student uttaler at veiledere trolig synes det er vanskelig å gi veiledning og kanskje ikke helt skjønner hvorfor de skal drive opplæring av studenter med fagarbeiderbakgrunn.

\section{Funn lukkede spørsmål}

Relevans, sammenheng mellom studiets faglige komponenter og veiledning

Tabell 1 viser hva studentene i første studieår i gjennomsnitt (M) har svart på de ulike spørsmålene knyttet til de faglige komponentene i studiet, spredningen i svarene deres (standardavvik) og hvordan svarene på de ulike spørsmålene relaterer seg til hverandre (Pearsons r). Tabell 2 gir de samme opplysningene, men da for studenter i tredje studieår.

Tabell 1 viser at studentene i første studieår i gjennomsnitt er enige $\mathrm{i}$ at undervisningen i yrkesfaget og profesjonsfaget er relevant (henholdsvis $M=5,12$ og $5,35)$. Det samme gjelder yrkespedagogisk praksis $(M=5,21)$. For yrkesfaglig praksis er gjennomsnittsverdien 4,73, noe som er litt lavere enn for de tre andre komponentene (verdien 4 indikerer litt enig, verdien 5 enig). Minst fornøyd er studentene med veiledningen i yrkesfaglig praksis som har en gjennomsnittsverdi på 4,50 .

Videre viser analysene at det er en sterk sammenheng mellom studentenes opplevelse av god veiledning i yrkesfaglig praksis og det å være fornøyd med yrkesfaglig praksis $\left(\mathrm{r}=0,61^{* *}\right)$. Det er også sterk sammenheng mellom studentenes opplevelse av relevant yrkesfaglig praksis og hvor fornøyde de er med denne praksisen $\left(r=0,69^{* *}\right)$. God veiledning og relevans i den yrkespedagogiske praksisen har også en signifikant sammenheng med hvorvidt studentene er fornøyde med sin yrkesfaglige praksis (henholdsvis $r=0,23^{* *}$ og $r=0,20^{* *}$ ).

Det er derimot en svakere relasjon mellom studentenes opplevelse av relevant undervisning i yrkesfaget og deres fornøydhet med yrkesfaglig praksis ( $\mathrm{r}=$ 
Yrkesfaglig praksis i bachelorutdanningen for yrkesfaglærere

$\left.0,15^{\star}\right)$, mens det er ingen signifikant sammenheng mellom studentenes opplevelse av relevant undervisning i profesjonsfaget og i hvilken grad de er fornøyde med denne praksisen.

Tabell 1. Studentenes fornøydhet med yrkesfaglig praksis sett i relasjon til deres opplevelse av veiledning og relevans $i$ studiet. Korrelasjoner forste studieår.

\begin{tabular}{|c|c|c|c|c|c|c|c|c|}
\hline & & 1 & 2 & 3 & 4 & 5 & 6 & 7 \\
\hline 1 & Fornøyd med yrkesfaglig praksis & 1 & & & & & & \\
\hline 2 & Fornøyd veiledning yrkesfaglig praksis & $61^{\star *}$ & 1 & & & & & \\
\hline 3 & Relevant yrkesfaglig praksis & $69^{\star *}$ &, $51^{\star \star}$ & 1 & & & & \\
\hline 4 & Fornøyd veiledning yrkespedagogisk praksis & $23^{\star *}$ & $28^{* \star}$ & $26^{\star *}$ & 1 & & & \\
\hline 5 & Relevant yrkespedagogisk praksis & $20^{\star *}$ & $25^{\star \star}$ & $31^{\star *}$ &, $53^{* *}$ & 1 & & \\
\hline 6 & Relevant undervisning yrkesfaget & $15^{*}$ & $25^{\star *}$ & $30^{\star *}$ & 08 & $20^{\star *}$ & 1 & \\
\hline \multirow[t]{3}{*}{7} & Relevant undervisning profesjonsfaget & 06 & $13^{*}$ & ,12 & $18^{\star *}$ & $36^{\star *}$ &, $32^{* *}$ & 1 \\
\hline & Gjennomsnitt (M) & 4,72 & 4,50 & 4,73 & 4,90 & 5,21 & 5,12 & 5,35 \\
\hline & Standardavvik & 1,28 & 1,39 & 1,27 & 1,35 & 1,01 & 94 & 93 \\
\hline
\end{tabular}

Merknad. $\mathrm{n}=252,{ }^{*} p<.05 . * * p<.01$

Tabell 2. Studentenes fornøydhet med yrkesfaglig praksis sett $i$ relasjon til deres opplevelse av veiledning og relevans $i$ studiet. Korrelasjoner tredje studieår.

\begin{tabular}{|c|c|c|c|c|c|c|c|c|}
\hline & & 1 & 2 & 3 & 4 & 5 & 6 & 7 \\
\hline 1 & Fornøyd med yrkesfaglig praksis & 1 & & & & & & \\
\hline 2 & Fornøyd veiledning yrkesfaglig praksis &, $78^{\star \star}$ & 1 & & & & & \\
\hline 3 & Relevant yrkesfaglig praksis &, $77^{\star \star}$ &, $59 * *$ & 1 & & & & \\
\hline 4 & Fornøyd veiledning yrkespedagogisk praksis & $46^{\star *}$ & $47^{\star \star}$ & $45^{\star \star}$ & 1 & & & \\
\hline 5 & Relevant yrkespedagogisk praksis &, $52^{\star \star}$ & $46^{\star \star}$ & $61^{\star *}$ & $67^{\star *}$ & 1 & & \\
\hline 6 & Relevant undervisning yrkesfaget &, $18^{*}$ & $18^{*}$ & $28^{\star *}$ & 14 & $26^{* *}$ & 1 & \\
\hline \multirow[t]{3}{*}{7} & Relevant undervisning profesjonsfaget & $31^{\star *}$ & $27^{\star *}$ &, $34^{\star \star}$ & $42^{* \star}$ &, $52^{\star *}$ & $40^{* *}$ & 1 \\
\hline & Gjennomsnitt (M) & 4,84 & 4,90 & 4,72 & 5,15 & 5,04 & 4,95 & 5,05 \\
\hline & Standardavvik & 1,16 & 1,13 & 1,20 & 1,28 & 1,29 & 1,02 & 1,17 \\
\hline
\end{tabular}

Merknad. $\mathrm{n}=150,{ }^{*} p<.05 .{ }^{* *} p<.01$. 
To år senere, ved slutten av tredje studieår (Tabell 2), viser analysene at studentene i gjennomsnitt fortsatt er enige $i$ at undervisningen i yrkesfaget og profesjonsfaget samt den yrkespedagogiske praksisen er relevant (henholdsvis $\mathrm{M}=4,95 ; 5,05 ; 5,15)$. Alle disse tre verdiene er litt lavere enn to år tidligere, mens gjennomsnittsverdien for opplevelsen av relevans i yrkesfaglig praksis er stabil $(M=4,73)$. Opplevelsen av å være fornøyd med veiledningen har økt fra 4,50 til 4,90. T-test, som sammenligner gjennomsnitt, viser at det kun er på spørsmålet om hvor fornøyde studentene er med veiledningen i yrkesfaglig praksis at vi finner en signifikant endring fra første til tredje studieår. Endringen er også positiv for yrkespedagogisk praksis, men denne endringen er ikke signifikant.

Videre viser korrelasjonsanalysene at sammenhengen er forsterket mellom studentenes opplevelse av god veiledning i yrkesfaglig praksis og det å være fornøyd med yrkesfaglig praksis (fra $r=0,61^{* *}$ til $0,78^{* *}$ ). Det samme gjelder opplevelsen av relevans i yrkesfaglig praksis og studentenes opplevelse av å være fornøyde med yrkesfaglig praksis (fra $\mathrm{r}=0,69^{* *}$ til $0,77^{* *}$ ). Opplevelsen av god veiledning og relevans i yrkespedagogisk praksis har også en klart forsterket sammenheng med hvorvidt studentene er fornøyde med sin yrkesfaglige praksis (henholdsvis fra $r=0,23^{* *}$ til $r=0,46^{* *}$ og fra $r=0,20^{* *}$ til $0,52^{* *}$ ). Styrken på sammenhengen mellom studentenes opplevelse av relevans i undervisningen $i$ yrkesfaget og fornøydhet med yrkesfaglig praksis er omtrent den samme i første og tredje studieår. Styrken på sammenhengen mellom studentenes opplevelse av relevans i undervisningen i profesjonsfaget og fornøydhet med yrkesfaglig praksis er tydelig styrket (fra $\mathrm{r}=0,06$ til $0,31^{* *}$ ).

I multivariat dataanalyse (Tabell 3), hvor man kontrollerer for effekten av hver av de ulike forklaringsvariablene (spørsmålene) som inngår i analysen, er det opplevelsen av relevans og god veiledning i yrkesfaglig praksis som i stor grad forklarer hvor fornøyde studentene er med denne praksisen (75 prosent). Ingen av de andre faktorene som er undersøkt, som for eksempel undervisning i profesjonsfaget og yrkesfaget viser seg å ha en selvstendig effekt på hvor fornøyde studentene er med yrkesfaglig praksis. 
Yrkesfaglig praksis i bachelorutdanningen for yrkesfaglærere

Tabell 3. Fornøyd med yrkesfaglig praksis, tredje studieår.

\begin{tabular}{lcccc}
\hline & B & beta & t-verdi & sign \\
\hline Fornøyd veiledning yrkesfaglig praksis &, 50 &, 49 & 9,11 &, 00 \\
Relevant yrkesfaglig praksis &, 47 &, 48 & 8,16 &, 00 \\
Fornøyd veiledning yrkespedagogisk praksis &, 02 &, 02 &, 34 &, 74 \\
Relevant yrkespedagogisk praksis &,- 01 &,- 02 &,- 24 &, 81 \\
Relevant undervisning yrkesfaget &,- 06 &,- 05 & $-1,13$ &, 26 \\
Relevant undervisning profesjonsfaget &, 03 &, 03 &, 64 &, 52 \\
Konstant &, 28 & &, 882 &, 38 \\
\hline
\end{tabular}

Merknad. R square $=0,75$

\section{Diskusjon}

Gjennom innsikt i studentenes erfarte læreplan vil vi diskutere hvordan vi kan forstå studentenes opplevde relevans, sammenheng og veiledning i yrkesfaglig praksis, og hvordan disse endres gjennom studiet.

\section{Relevans i yrkesfaglig praksis}

Innsikt i og forståelse av forskrift om rammeplan for yrkesfaglærerutdanning og de lokale studieplanene er utgangspunktet for studentenes valg av yrkesfaglig praksis. Den formelle læreplanen ligger altså til grunn for den iverksatte. Goodlads (1979) fem læreplannivåer, fra ide til erfaringer, er som beskrevet innledningsvis brukt som redskap for å utforske hvorvidt yrkesfaglig praksis i yrkesfaglærerutdanningen ved NTNU har et innhold og en organisering som bidrar til en opplevelse av relevans.

De kvantitative funnene viser at de fleste studentene opplever at yrkesfaglig praksis er relevant, noe som underbygges av svarene i de åpne spørsmålene. Gjennom praksis får de kjennskap til yrkenes egenart og arbeidsfunksjoner/operasjoner. Flere peker på at de har prøvd ut yrker de kunne lite om og at disse erfaringene er nødvendige for å få innsikt og innblikk i de ulike fagene innenfor eget utdanningsprogram. Dette gir yrkesfaglig breddekompetanse. Videre peker studenter på muligheter for oppdatering og fordypning i eget fagbrevområde, noe som gir yrkesfaglig dybdekompetanse. Erfaringene fra yrkesfaglig praksis gjør det lettere å planlegge og gjennomføre undervisning og veilede elever. Eksemplene som studentene gir på sine læringsutbytter samsvarer godt med den formelle læreplanen for studiet. Hiim og Hippe (2001) etterspør relevans knyttet 
til praktisk yrkesutøvelse i yrkes- og profesjonsutdanninger. I denne sammenheng vil yrkesfaglig praksis være et viktig bidrag for å styrke profesjonsrelevansen til yrkesfaglærere.

Selv om de fleste studentene er enige i at yrkesfaglig praksis er relevant opplever de at undervisningen i profesjons- og yrkesfaget og praksis i skole er mer relevant (Tabell 1 og 2). Noen studenter med lang yrkeserfaring eller flere fagbrev opplever at denne praksisen er sløsing av tid, mens andre uttaler at praksisen er for lang og ønsker mer yrkespedagogisk praksis på bekostning av den yrkesfaglige. Dette er de samme signalene som fremkommer i evalueringen av yrkesfaglærerutdanningen fra 2003 hvor 20 prosent av studentene svarer at det er for mye yrkesfaglig praksis i yrkesfaglærerutdanningen (Brandt \& Hatlevik, 2003).

Uttalelsen "en til to uker er bedre enn fire uker i samme bedrift" går igjen i de tidlige undersøkelsene. De første årene etter at studiet ble opprettet ved NTNU ble studentene anbefalt å ha minimum to uker, gjerne fire uker i samme bedrift/virksomhet. Som et svar på studentenes tilbakemeldinger og læringsbehov, har rammene blitt endret. I dag er det mulig å ha 5-20 dagers yrkesfaglig praksis i samme bedrift. En annen endring er at det nå gis mulighet for fritak i maks 10 arbeidsdager per studieår for studenter med lang, dokumentert yrkeserfaring eller flere fagbrev innenfor eget utdanningsprogram. En tredje endring som er iverksatt, etter forslag fra studentene, er en kartlegging av individuelle behov for yrkesfaglig praksis tidlig i studiet (2. semester). Dette foregår på et seminar hvor tidligere studenter og representanter fra arbeidslivet bidrar og veileder studentene sammen med yrkesfaglærerutdannerne. Det er viktig at vi sammen med hver enkelt student legger til rette for valg av relevant yrkesfaglig praksis som bidrar til utvikling av bredde- og dybdekompetanse, pedagogisk og didaktisk kompetanse samt nettverksbygging innenfor sitt utdanningsprogram. Studenter påpeker at den yrkesfaglige praksisen må styrkes og organiseres bedre fordi den er svært viktig enten de liker den eller ikke.

Valg av relevant yrkesfaglig praksis dreier seg også om en ansvars- og bevisstgjøring hos studentene. Målet er de skal unngå lettvinte løsninger mer tilpasset andre behov (økonomi, familiære, tid og lignende) enn deres egne læringsbehov. Vår erfaring er at studentene i tredje studieår tar mer veloverveide valg med utgangspunkt i egne læringsbehov, noe som kan være en grunn til sterkere korrelasjoner mellom relevans, veiledning og fornøydhet i tredje studieår sammenlignet med første. Studentene er også signifikant mer fornøyd med veiledning i yrkesfaglig praksis i tredje studieår enn hva tilfellet var to år tidligere. Med økt bevissthet på praksisens formål kan studentene sørge for å velge mer relevante praksisplasser og kvalifiserte veiledere.

Noen studenter etterspør en tydeligere beskrivelse av hva de skal giøre i yrkesfaglig praksis. Det kan være et signal om at den formelle læreplanen ikke er operasjonalisert på en god nok måte, eller at vår, altså yrkesfaglærerutdannernes, oppfattede læreplan og studentenes oppfattede læreplan er i ubalanse. Selv om 
vi mener at kompetansemålene i den formelle læreplanen er tydelige, må dette forbedres så lenge studentene opplever at instruksene er uklare. Opplevelse av relevans, sammen med god veiledning, forklarer i stor grad hvor fornøyd studentene er med den yrkesfaglige praksisen (Tabell 3). A jobbe systematisk og målrettet med dette for øye blir derfor essensielt.

\section{Sammenhenger mellom yrkesfaglig praksis og studiets øorige komponenter}

Den formelle læreplanen sier at utdanningen skal være av høy faglig kvalitet, og med "helhet og sammenheng" mellom profesjonsfag, yrkesfag og praksis (Kunnskapsdepartementet, 2013b). Kjennetegnene helhet og sammenheng er sterkt forankret i ideenes læreplan for treårig yrkesfaglærerutdanning. Dette synliggjøres blant annet i NOU 1996: 22 Lærerutdanning: Mellom krav og ideal hvor utvalget foreslo at det ble etablert en ny hovedmodell for utdanning av yrkesfaglærere på bachelornivå der den yrkesteoretiske og pedagogiske utdanningen var integrert. Hovedmodellen skulle bestå av komponentene pedagogikk, didaktikk, bredde og fordypning. Studiet skulle forankres i fire prinsipper hvorav det ene var helhet og sammenheng (Regjeringen, 1996). Utvalgets utredning ble fulgt opp i St. meld. nr. 48 (1996-97) Om lærerutdanning. Kirke-, utdannings- og forskningsdepartementet forslo her å opprette en treårig yrkesfaglærerutdanning fra år 2000 basert på utvalgets modell og prinsipper (Regjeringen, 1997).

Vi har valgt å tolke studentenes erfaringer med helhet og sammenheng i et lærings- og mestringsperspektiv der disse forstås som meningsdanning og noe en søker etter der ulike emner og erfaringer ses opp mot og forstås i lys av hverandre (Hatlevik \& Havnes, 2017). Svake korrelasjoner mellom en del av komponentene i studiet (Tabell 1 og 2) og en regresjonsanalyse (Tabell 3) der veiledning og relevans forklarer omtrent all variasjonen i studentenes fornøydhet med praksis tyder på at intensjonen om helhet og sammenheng mellom studiets ulike komponenter ikke er oppfylt i ønskelig grad.

Studien til Brandt og Hatlevik (2003) viser at yrkesfaglærerutdannere ved andre campuser også erfarer at det å skape helhet og sammenheng $\mathrm{i}$ utdanningen er utfordrende og krevende. Enkelte lærere sier at dette ikke blir ivaretatt etter intensjonen i rammeplanen. Det blir også hevdet at undervisningen blir for fragmentert og at teorien ikke ble godt nok koblet til den yrkesfaglige praksisopplæringen. Dette understøttes av Hatlevik og Havnes (2017) som peker både på at kunnskapselementer fra ulike fagfelt ofte ikke henger godt nok sammen og at koblingen mellom læring på ulike læringsarenaer er for svak innenfor profesjonsutdanningene.

Når det er sagt, svarer mange studenter i denne studien at yrkesfaglig praksis skaper større forstålse for fagene og knytter teori og praksis bedre sammen. Det blir lettere å planlegge undervisning og forutsetningene for å integrere praksis $\mathrm{i}$ egen undervisning styrkes. Større innsikt i og oppdatert kunnskap om yrkene 
oppleves å være til god hjelp i blant annet Yrkesfaglig fordypning, i veilederrollen på Vg1 og i rådgivning om yrkesvalg. Illeris (2012) peker på at avstanden mellom utdanningsinstitusjonene og arbeidsplassene gjør det utfordrende, både for yrkesfaglærerutdannere og yrkesfaglærerstudenter, å følge med på de raske endringene som skjer i et moderne arbeidsliv. Yrkesfaglig praksis vil kunne motvirke dette og bidra til at avstanden mellom institusjonene og bedriftene minskes.

Funn fra de kvantitative analysene viser at det er sterkere korrelasjoner mellom hvor fornøyde studentene er med yrkesfaglig praksis og en rekke andre komponenter i studiet $\mathrm{i}$ tredje studieår (Tabell 2) sammenlignet med første (Tabell 1). Studien viser at det ofte skjer en utvikling hos studentene fra første til tredje studieår hvor de går fra å oppleve studiet mer fragmentert til å se helheten og formålet med studiet mer tydelig. Dette viser seg blant annet gjennom at tredjeårsstudenter svarer at yrkesfaglig praksis får stor betydning sett i ettertid. Svarene indikerer at de er mer reflekterte og uttalelsene er mer nyanserte. Studentene tar også mer ansvar for egen læring i tredje studieår sammenlignet med første. Uttalelsen "Praksisperiodene er hva du selv gjør dem til" uttrykker dette.

Studenter som deltar og opplever helhet, sammenheng og relevans opplever å ha bedre læringsutbytte (Aamodt m.fl., 2007). Vi har, i likhet med studier på studiekvalitet (Hammerness, 2013), en implisitt forståelse av at sterke sammenhenger indikerer kvalitet på studiet. Hiim (2007) skriver at for oss som lærerutdannere er det viktig å legge til rette for sammenhengende læring for studentene som legger grunnlag for et helhetlig, flerdimensjonalt kunnskapsbegrep. Den iverksatte læreplanen blir avgjørende for at studentene skal få mulighet til å oppleve helhet. Vi må derfor blant annet se på arbeidskrav knyttet til yrkesfaglig praksis og sørge for at disse bidrar til å hjelpe studentene å se sammenhenger mellom studiets ulike komponenter.

\section{Veiledning}

Forskrift om rammeplan for yrkesfaglærerutdanning presiserer at den yrkesfaglige praksisen skal være veiledet og retningslinjene angir 60 timer, gjennomsnittlig en time per dag (Kunnskapsdepartementet, 2013a, b). Tabell 1 og 2 viser sterke korrelasjoner mellom det å være fornøyd med veiledning i og det å være fornøyd med yrkesfaglig praksis, og denne sammenhengen er sterkere i tredje studieår enn i første. Dette understøttes av de kvalitative funnene der studentene ofte oppgir god veiledning og flinke veileder når de gir tilbakemelding om at de har hatt en god praksisopplevelse.

Dyktige veiledere er for mange studenter viktig for en god praksisopplevelse. Noen av veilederne beskrives som meget dyktige og innehar trolig kompetansen som Tveiten (2013) påpeker er sentral. Disse veilederne bør få tilbakemelding om at de gjør en god jobb slik at deres motivasjon for å ta imot nye studenter holdes ved like. Noen ganger bør også yrkesfaglærerutdannerne ta kontakt med praksisveilederen for å gi positiv tilbakemelding. Gjennom en slik kontakt vil både 
studenten og utdanningsinstitusjonen bygge et faglig nettverk til bedrifter/virksomheter (Illeris, 2012).

Andre veiledere beskrives som uforberedte, tafatte, ikke tilstedeværende og/eller uten tilstrekkelig kompetanse. Studenter som gir slike tilbakemelding er mindre fornøyd med sin yrkesfaglige praksis. Hvis veilederen ikke forstår hva som forventes av dem vil det være vanskelig å forberede seg og gjøre en god veiledningsjobb. Det er derfor viktig at lærerutdanningene utvikler og tilbyr kompetanseheving for veiledere som er i tråd med Yrkesfaglærerløftets strategi for kompetanseheving (Kunnskapsdepartementet, 2015).

Det er viktig for en student å følge og observere sin veileder gjennom en normal arbeidsdag. Studenten bør prøve ut arbeidsoperasjoner under veiledning for egen kompetanseutvikling (Brenner, 1983; Schön, 1982, 1987). Fagfolk besitter en spisskompetanse, men utførelsen av arbeidsoperasjonen kan være så "mekanisert" at fagpersonen ikke lenger ser kompleksiteten i sitt eget arbeid og ikke er bevisst at han har et spesielt triks eller bruker fingerspissfølelsen. Veilederen kan ha mange års erfaring, men erfaringskompetansen er kanskje aldri uttalt - verken skriftlig eller muntlig. Det er viktig at veilederne blir bevisste sin skjulte kunnskap og tenker gjennom hvordan de kan formidle den til praksisstudenten - både gjennom handling og ord (McNiff, 2013). Observasjon, refleksjon og samtale omkring arbeidsoperasjoner vil være sentralt mellom student og veileder. Tid til refleksjon er vesentlig for studentens læringsutbytte i yrkesfaglig praksis (Ramlo, 2016; Rautkorpi \& Hero, 2017).

Det er essensielt for læring å være en del av praksisfellesskapet og delta i alle sosiale sammenhenger som planleggingsmøter, formelle og uformelle pauser (Lave \& Wenger, 2004). Gjennom deltagelse i praksisfellesskapet vil studenten kunne få uformell veiledning av andre fagfolk på arbeidsplassen. Veiledernes oppgave vil være å hjelpe studenten inn i fellesskapet gjennom å ta studenten med på kaffepauser, lunsj og møter. Tilhørighet i praksisfellesskapet vil kunne danne grunnlaget for læring og økt fornøydhet med yrkesfaglig praksis.

Studentene har erfart at god veiledning er essensielt for opplevd relevans i yrkesfaglig praksis. Sammenhengene er sterkere i tredje studieår enn i første (Tabell 1 og 2). Svar på de åpne spørsmålene indikerer i tillegg at studentene i tredje studieår er mer faglig bevisste i valg av praksissted sammenlignet med første- og andreårsstudentene. Tredjeårsstudentene har et større nettverk blant sine medstudenter og yrkesfaglærerutdannere og har hatt bedre mulighet for erfaringsutveksling, og de kan dermed gjøre mer informerte valg av bedrift/virksomhet.

\section{Studiens begrensninger}

Studien og datamaterialet har sine begrensninger. Vi vil omtale svarprosenten og operasjonaliseringer av begrep. Mellom 60 og 65 prosent av studentene har svart på undersøkelsene. Av de som har svart kommer omtrent halvparten fra helse- 
og oppvekstfag og i underkant av hver fjerde representerer restaurant- og matfag. Det indikerer at en større andel studenter fra disse to studieretningene har svart sammenlignet med de teknologiske fagene. Ved oppstart 1. studieår er 38 prosent fra helse- og oppvekstfag, 48 prosent fra teknologiske fag og 14 prosent fra restaurant- og matfag. Vi vet at frafallet gjennom studiet er minst på helse- og oppvekstfag og restaurant- og matfag (Rokkones, Landro \& Utvær, 2018) slik at andelene som har svart fra disse to studieretningene nærmer seg populasjonen.

Studien tar utgangspunkt i Forskrift om rammeplan for yrkesfaglærerutdanning, dens retningslinjer og studieplanen for det treårige bachelorprogrammer ved NTNU. I disse dokumentene brukes begrep vi har operasjonalisert. I metodedelen gir vi eksempler på spørsmålsformuleringene brukt i operasjonaliseringene av begrepene relevans og veiledning. Når vi stiller spørsmål til studentene om yrkesfaglig praksis har vært relevant, vet vi ikke spesifikt hva de legger i relevansbegrepet. Det er uklart om de vektlegger bredde-, dybde- og/eller profesjonskompetanse. De åpne spørsmålene i studien er en styrke, da de åpner opp for å kunne spesifisere og utdype nærmere hvilken kompetanse studentene opplever å ha fått.

Til sist vil vi bemerke er at vi kun har fått innsikt i det studentene selv sier at de har lært, ikke hva de faktisk kan. Selv om de er fornøyd med yrkesfaglig praksis eller svarer at de er enig i at den er relevant, betyr ikke det at de har tilegnet seg den fastsatte kompetansen beskrevet i forskrift om rammeplan for yrkesfaglærerutdanning og studieplanen. Mer kunnskap om hva de faktisk har lært vil vært nyttig. Videre forskning på dette kunne omfattet mer nyanserte spørsmålsformuleringer i en survey, dybdeintervju eller aksjonsforskning der kunnskapen implementeres i praksis.

\section{Oppsummering}

Studien utforsker studentenes erfaringer med yrkesfaglig praksis for å videreutvikle og sikre at den er i samsvar med studiets formål med tanke på relevans, sammenheng og veiledning. Studien viser at yrkesfaglærerstudentene opplever at yrkesfaglig praksis har stor betydning for å lære om forskjellige yrker og arbeidsfunksjoner innenfor eget utdanningsprogram. Praksisen oppleves å være til god hjelp i arbeidet med å gjøre undervisningen mer praksisnær, knytte teori og praksis bedre sammen og veilede i faget Yrkesfaglig fordypning, spesielt på Vg1, hvor elevene skal gjøre yrkesvalg. Yrkesfaglig praksis bidrar også til å styrke kompetansen til å undervise på Vg2 og veilede i bedrift. Funn fra de kvantitative analysene viser at det er sterkere korrelasjoner mellom hvor fornøyde studentene er med yrkesfaglig praksis og en rekke andre komponenter i tredje studieår sammenlignet med første. Studentene utvikler seg fra første til tredje studieår hvor de går fra å oppleve studiet noe fragmentert til å se helheten og formålet med 
studiet mer tydelig. I tredje studieår er det studenter som sier at yrkesfaglig praksis oppleves å være like viktig som yrkespedagogisk praksis og at denne praksisen får stor betydning, sett i ettertid.

\section{Noter}

${ }^{1}$ Videregående trinn $1+2(\mathrm{Vg} 1+\mathrm{Vg} 2)$.

2 Videregående trinn 3 (Vg3).

\section{Om forfatterne}

Klara Rokkones er førstelektor vid Institutt for lærerutdanning på Norges teknisk-naturvitenskapelige universitet. Hun har skrevet flere artikler om læreres læring og nå sist en artikkel i NJVET om etableringen av og erfaringene med bachelorprogrammet for yrkesfaglærere ved NTNU.

Berit Stjern er universitetslektor vid Institutt for samfunnsmedisin og sykepleie på Norges teknisk-naturvitenskapelige universitet. Hun er opptatt av voksnes læring og studentaktive undervisningsmetoder.

Åse Strand er førsteamanuensis vid Institutt for bioteknologi og matvitenskap på Norges teknisk-naturvitenskapelige universitet. Hun har i mange år vært fagleder for restaurant- og matfag ved yrkesfagutdanningen. Hun har vært opptatt av å uvikle studiet gjennom samarbeid om helhet og sammenheng.

Britt Karin Utvær er førsteamanuensis vid Institutt for lærerutdanning på Norges teknisk-naturvitenskapelige universitet. Hun har skrevet doktorgrad om frafall i videregående opplæring innenfor yrkesfag og har i den forbindelse tidligere publisert artikler om elevers motivasjon for å fullføre, deriblant i NJVET. 
Klara Rokkones, Berit Stjern, Åse Strand \& Britt Karin Utvær

\section{Referanser}

Aamodt, P.O., Prøitz, T.S., Hovedhaugen, E. \& Stensaker, B. (2007). NIFU 2007:40. Læringsutbytte i høyere utdanning: En drøfting av definisjoner, utviklingstrekk og måleproblemer. Oslo: NIFU.

Andersson, P. \& Köpsén, S. (2018). Maintaining competence in the initial occupation: Activities among vocational teachers. Vocations and Learning, 11(2), 317344.

Aspøy, T.M., Skinnarland, S. \& Tønder, A.H. (2017). Fafo 2017:11. Yrkesfaglærernes kompetanse. Oslo: Fafo.

Brandt, S.S. \& Hatlevik, I.K.R. (2003). NIFU 2003:38. Skreddersydd yrkesfaglærerutdanning? Oslo: NIFU.

Benner, P. (1983). From novice to expert: Excellence and power in clinical nursing practice. Menlo Park, Calif.: Addison-Wesley.

Dreyfus, H.L. \& Dreyfus, S.E. (1986). Mind over machine: The power of human institution and expertice in the era of the computer. New York: Free Press.

Engelsen, B.U. (2012). Kan læring planlegges? - Arbeid med læreplaner - hva, hvordan, hvorfor. Oslo: Gyldendal akademiske.

Fejes, A. \& Köpsén, S. (2014). Vocational teachers' identity formation through boundary crossing. Journal of Education and Work, 27(3), 265-283.

Goodlad, J.I. (1979). The scope of the curricular field. I: J.I. Goodlad m.fl., Curriculum inquiry: The study of curriculum practice. New York: McGraw Hill.

Hammerness, K.M. (2013). Examining features of teacher education in Norway. Scandinavian Journal of Educational Research, 57(4), 400-419.

Hansen, K., Hoel, T.L. \& Haaland, G. (Red.). (2015). Tett på yrkesopplæring. Bergen: Fagbokforlaget.

Hansen, K.H. \& Haaland, G. (2015). Utfordringer i norsk yrkesopplæring. I K. Hansen., T.L. Hoel \& G. Haaland (Red.), Tett på yrkesopplæring (s. 19-49). Bergen: Fagbokforlaget.

Hatlevik, I.K.R. \& Havnes, A. (2017). Perspektiver på læring i profesjonsutdanningene: Fruktbare spenninger og meningsfulle sammenhenger. I S. Mausethagen \& J-C. Smeby (Red.), Kvalifisering til profesjonell yrkesutøvelse (s. 191203). Oslo: Universitetsforlaget.

Heggen, K., Smeby, J.C. \& Vågan, A. (2015). Coherence: A longitudinal approach. I J-C. Smeby \& M. Sutphen (Red.), From vocational to professional education: Educating for social welfare (s. 70-88). New York: Routledge.

Hiim, H. \& Hippe, E. (2001). A utdanne profesjonelle yrkesutøvere. Oslo: Gyldendal akademisk.

Hiim, H. (2007). A strategy for practice-based education and research. I P. Ponte \& H.J. Smit (Red.), The quality of practitioner research (s. 97-114). Rotterdam: Sense Publishers. 
Hiim, H. (2013). Praksisbasert yrkesutdanning: Hvordan utvikle relevant yrkesutdanning for elever og arbeidsliv? Oslo: Gyldendal akademisk.

Hiim, H. (2015). Educational action research and the development of professional teacher knowledge. I E. Gunnarsson, H.P. Hansen \& B. Steen Nielsen (Red.), Action research for democracy (s. 147-161). London: Routledge.

Hiim, H. (2017). Ensuring curriculum relevance in vocational education and training: Epistemological perspectives in a curriculum research project aimed at improving the relevance of the Norwegian VET. International Journal for Research in Vocational Education and Training, 4(1), 1-19.

Hilsen, A. I., Nyen, T. \& Tønder, A.H. (2012). Fafo 2012:61. Hospitering $i$ fagopplaringen: Evaluering av forsøksordninger i eks fylker. Oslo: Fafo.

Høst, H. (2010). NIFU STEP 2010:25. Helsefagarbeiderutdanning for voksne. Oslo: NIFU STEP.

Illeris, K. (2012). Læring. Oslo: Gyldendal Akademisk.

Kunnskapsdepartementet. (2006). Rammeplan for yrkesfaglærerutdanning. Hentet den 04.04.2016 fra https://www.regjeringen.no/globalassets/upload/kilde/kd/pla/2006/0002/ddd/pdfv/270457-rammeplan_yrkesfagl_jan06.pdf

Kunnskapsdepartementet. (2013a). Nasjonale retningslinjer for treårig yrkesfaglxrerutdanning. Hentet den 04.04.2016 fra http://www.uhr.no/documents/nasjonale_retningslinjer_yfl_.pdf

Kunnskapsdepartementet. (2013b). Forskrift om rammeplan for yrkesfaglærerutdanning for trinn 8-13. Hentet den 04.04.2016 fra https://www.regjeringen.no/globalassets/upload/kd/vedlegg/rammeplanen/yrkesfaglaererutdanning.pdf

Kunnskapsdepartementet. (2015). Yrkesfaglærerløftet - for fremtidens fagarbeidere. Oslo: Kunnskapsdepartementet.

Kvale, S., Brinkmann, S., Anderssen, T.M. \& Rygge, J. (2015). Det kvalitative forskningsintervju (3. utg., 2. opplag). Oslo: Gyldendal akademiske.

Lave, J. \& Wenger, E. (2003). Situert læring. København: Hans Reitzels Forlag.

Lave, J. \& Wenger, E. (2004). Praksisfellesskaber. København: Hans Reitzels Forlag.

McNiff, J. (2013). Action Research: Principles and practice (3. utg.). New York: Routledge.

NTNU. (2017). Pedagogisk og yrkesfaglig praksisopplæring - Del 1. Hentet den 27.06.2018 fra https:/ / www.ntnu.no/studier/

Nyen, T. \& Tønder, A.H. (2012). Fafo 2012: 47. Fleksibilitet eller faglighet? En studie av innføringen av faget projekt til fordypning i Kunnskapsløftet. Oslo: Fafo.

Postholm, M.B. \& Jacobsen, D.I. (2014). Læreren med forskerblikk. Innføring i vitenskapelig metode for lærerstudenter. Kristiansand: Høyskoleforlaget.

Ramlo, S. (2016). Internasjonalisering gjennom studentmobilitet. Masteroppgave. Trondheim: NTNU. 
Rautkorpi, T. \& Hero, L-M. (2017). Promoting students' reflections in organizational improvisation arrangement between higher education and workplaces. Nordic Journal of Vocational Education and Training, 7(1), 1-22.

Regjeringen. (1996). NOU 1996:22. Lærerutdanning: Mellom krav og ideal. Oslo: Kirke-, utdannings- og forskningsdepartementet.

Regjeringen. (1997). St. meld. nr. 48 (1996-97). Om lærerutdanning. Oslo: Kirke-, utdannings- og forskningsdepartementet.

Rokkones, K., Landro, J. \& Utvær, B.K. (2018). Bachelorutdanning for yrkesfaglærere, i et historisk og utviklingsorientert perspektiv. Nordic Journal of Vocational Education and Training, 8(3) (i prosess).

Schön, D. (1982). The reflective practitioner: How professionals think in action. New York: Basic Books.

Schön, D. (1987). Educating the reflective practitioner. San Francisco, CA: JosseyBass.

Skålholt, A., Høst, H., Nyen, T. \& Tønder, A.H. (2013). NIFU 2005:5. Å bli helsefagarbeider. En kvalitativ undersøkelse av overganger mellom skole og læretid, og mellom læretid og arbeidsliv blant ungdom i helsearbeiderfaget. Oslo: NIFU.

Smeby, J-C. \& Mausethagen, S. (2017). Profesjonskvalifisering. I S. Mausethagen \& J-K. Smeby (Red.), Kvalifisering til profesjonell yrkesutøvelse (s. 11-20). Oslo: Universitetsforlaget.

Spetalen, H. (2014). Yrkesfaglæreren: Ny rolle, nye utfordringer. Nordic Journal of Vocational Education and Training, 4, 1-9.

Tveiten, S. (2013). Veiledning- mer enn ord (4. utg.). Bergen: Fagbokforlaget.

Utvær, B.K. \& Haugan, G. (2016). The academic motivation scale: Dimensionality, reliability, and construct validity among vocational students. Nordic Journal of Vocational Education and Training, 6(2), 17-45. 